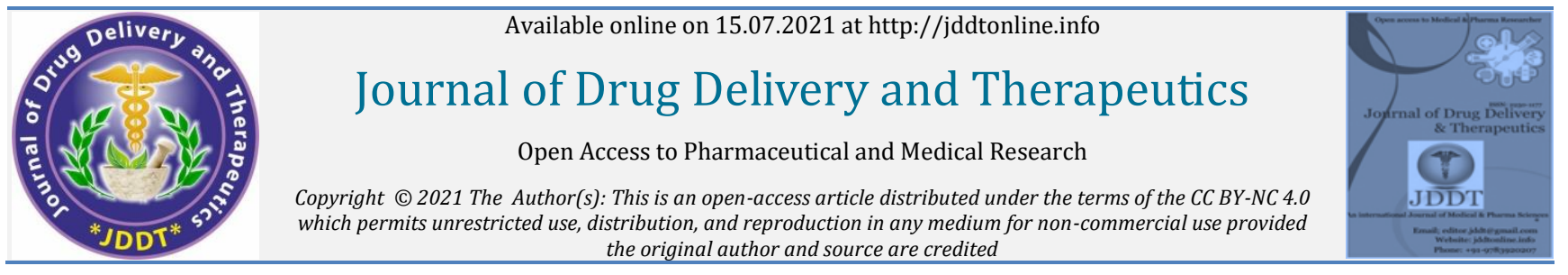
the original author and source are credited

Ope

\title{
Physicochemical, ADMET and Druggable properties of Myricetin: A Key Flavonoid in Syzygium cumini that regulates metabolic inflammations
}

\author{
C. Soorya ${ }^{1}$, S. Balamurugan², S. Ramya ${ }^{3}$, K. Neethirajan³ ${ }^{3}$ C. Kandeepan ${ }^{4}$, R. Jayakumararaj1* \\ ${ }^{1}$ Department of Botany, Government Arts College, Melur - 625 106, Madurai, TamilNadu, India
}

${ }^{2}$ Department of Mathematics, Government Arts College, Melur - 625 106, Madurai, TamilNadu, India

${ }^{3}$ Department of Zoology, Yadava College for Men, Tirupalai- 625 017, Madurai, TamilNadu, India

${ }^{4}$ PG and Research Department of Zoology, Arulmigu Palaniandavar College of Arts and Culture, Palani - 624601, Dindigul District, TamilNadu, India

Article Info:

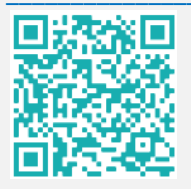

Article History:

Received 22 May 2021

Review Completed 27 June 2021

Accepted 07 July 2021

Available online 15 July 2021

\section{*Address for Correspondence:}

R. Jayakumararaj, Department of Botany, Government Arts College, Melur - 625 106, Madurai, TamilNadu, India

\section{Cite this article as:}

Soorya C, Balamurugan S, Ramya S, Neethirajan K, Kandeepan S, Jayakumararaj R, Physicochemical, ADMET and Druggable properties of Myricetin: A Key Flavonoid in Syzygium cumini that regulates

metabolic inflammations , Journal of Drug Delivery and Therapeutics. 2021; 11(4):66-73

DOI: http://dx.doi.org/10.22270/jddt.v11i4.4890

\section{Abstract}

Syzygium cumini (Myrtaceae) is a potential medicinal plant traditionally used in indigenous systems of medicines practiced in India and elsewhere due to its functional properties against metabolic inflammations viz., anti-hyperglycemic, anti-inflammatory, cardioprotective, and antioxidant activities. Targeting metabolic inflammation has emerged as a standalone strategy to attenuate metabolic disease. Myricetin $\left(3,5,7,3^{\prime}, 4^{\prime}, 5^{\prime}\right.$ hexahydroxyflavone) is one of the flavonoids from stem bark, leaf, flowers, fruits, pulp and seeds of S. cumini. Therefore, attention has been paid to explore bioactive potentials of this compound in $S$. cumini owing to its exemplary therapeutic prospective and healthpromoting effects. Antioxidant effect of Myricetin from S. cumini has been though experimentally demonstrated, therapeutic potential of Myricetin has not been fully explored. In the present study, physicochemical, ADMET and druggability properties of Myricetin - a key flavonoid compound in S. cumini have been evaluated. Data implicates that this molecule of GRAS standard can be a novel jumble-sale lead in drug discovery.

Keywords: Plant Based Natural Products (PBNPs); Drug Discovery; Pharmacological Activity; ADMET Properties; Flavonoid; Myricetin; Syzygium cumini

\section{INTRODUCTION}

Diabetes mellitus (DM) an epidemic, affects more than 170 million individuals worldwide. It is predominantly characterized by chronic, low-grade and systemic inflammation. Human body maintains blood glucose level within a narrow range, regulated by insulin - glucagon metabolism. Insulin induces liver cells to take up glucose from blood and store it in the form of glycogen whereas glucagon stimulates liver cells to secrete glucose into blood cells for production of ATP. Diabetics, a metabolic disorder results due to impairment of biochemical pathways responsible for production of insulin and the resultant metabolic inflammation. About $90 \%$ of individuals have Type II diabetes which is characterized by high levels of glucose in blood.

As of now, there are five major classes of oral pharmacological agents available in the market to treat diabetes however, with side effects. Moreover, the limited long-term durability of immunotherapy and undesirable side effects of anti-diabetic drugs underlie the need for alternative therapeutics. Phytochemicals are rich source of ISSN: 2250-1177 plant based natural products (PBNPs) that are of pivotal importance with therapeutic potential in the management of diabetes.

Metabolic inflammation is well established as a critical feature of diabetes, and evident in the pancreas, liver, adipose tissue, muscle, and other organs actively involved in glucose metabolism. Furthermore, metabolic inflammation is profoundly modulated by various mediators of innate and adaptive immunity, making inflammation as the nexus within the crosstalk among key events in the pathogenesis of diabetes $^{1}$. Given that metabolic inflammation is a key pathophysiological event that drives the progression of diabetes, protective effects of phytochemicals in metabolic inflammation needs in-depth investigation.

As said, plants provide a large repertoire of phytochemicals such as polyphenols, flavonoids, carotenoids and vitamins that are used as active ingredients of drugs in modern age ${ }^{2}$. Plant Based Natural Products (PBNPs) are associated with minimal side effects as compared to synthetic drugs and have gained much interest. More than 25000 phytochemicals 
have been identified to date, including 8000 different types of polyphenols for their therapeutic potential ${ }^{3}$.

Flavonoids consist of a large group of polyphenolic compounds having a benzo- $\gamma$-pyrone structure ubiquitously present in plants, synthesized through phenylpropanoid pathway. Secondary metabolites of phenolic nature including flavonoids are responsible for the variety of pharmacological activities 4 . Flavonoids, the most abundant polyphenol antioxidants in human diets, have been reported to be absorbed in humans, circulate in plasma and are excreted in urine. Flavonoids have antioxidant activity, free radical scavenging capacity, metal chelation activity, coronary heart disease prevention, hepatoprotective, anti-inflammatory, and anticancer activities 4 . As of now, more than 4000 varieties of flavonoids from various plant sources have been reported 5 .

Myricetin, a common plant-derived flavonoid is well recognised for its nutraceuticals value. It is a key ingredient in various foods and beverages. Myricetin is a hexahydroxyflavone that is flavone substituted by hydroxyl groups at positions $3,3^{\prime}, 4^{\prime}, 5,5^{\prime}$ and 7 . Myricetin is a polyhydroxyflavonol compound composed of light yellow crystals, soluble in methanol, acetonitrile, ethanol and other polar solvents. Its chemical formula is $\mathrm{C}_{15} \mathrm{H}_{10} \mathrm{O}_{8}$ and the relative molecular mass is 318.246 .

It was first described in $18^{\text {th }}$ century from the bark of Myrica nagi Thunb. Myricaceae 7 , later from the leaves of Myrica rubra and other plants. This compound is very common in berries, vegetables, teas and wines produced from various plants ${ }^{8}$. Although Myricetin occurs throughout the Plant Kingdom, it is produced mainly by members of the families: Mangifera indica (Anacardiaceae) ${ }^{9,10}$, Marantodes pumilum (Primulaceae) ${ }^{11}$, Polygonaceae ${ }^{12}$, and Primulaceae ${ }^{13}$. Myricetin plays a vital role as cyclooxygenase 1 inhibitor, it down-regulates phorbol ester-induced cyclooxygenase-2 expression in mouse epidermal cells by blocking activation of nuclear factor kappa $\mathrm{B}^{14}$. Myricetin serves as an antineoplastic agent, an antioxidant, a food component and a hypoglycemic agent. It is a hexahydroxyflavone and a 7hydroxyflavonol.

Pharmacological studies have proved that Myricetin possesses a variety of biological activities such as antiinflammatory, antitumor, antibacterial, antiviral, antiobesity, cardio-protective, neuro-protective, and hepatoprotective effects. Studies have demonstrated its activity against DNA polymerases, RNA polymerases, reverse transcriptases, telomerases, kinases and helicases ${ }^{15}$.

Myricetin is used in the management of non-insulindependent diabetes, by stimulating the uptake of glucose without functional insulin receptors ${ }^{16}$. The effect of Myricetin was evaluated in diabetes mellitus-associated kidney injuries and dysfunction in an experimental mouse model induced by 5 consecutive injections of low-dose streptozotocin (STZ). Data revealed that Myricetin (Oral, $100 \mathrm{mg} / \mathrm{kg} / \mathrm{day}$, for $6 \mathrm{M}$ ) inhibited $\mathrm{I} \kappa \mathrm{B} \alpha / \mathrm{NF}-\kappa \mathrm{B}$ pathway independent of nuclear factor erythroid 2-related factor (Nrf2) regulation. Furthermore, it activated glucagon-like peptide 1 receptor (GLP-1R) and its long-term oral administration (200 mg/kg, for 40D) validates its gluco-regulatory effects ${ }^{17}$. Based on the results it was concluded that Myricetin acts as a natural class B GPCR antagonist for the treatment of T2D. Accumulating evidence suggests that Myricetin possesses antidiabetic properties that are mediated via regulation of the transport of glucose through the function of glucose transporter-2 in Xenopus laevis oocytes ${ }^{18}$. Karunakaran et al. ${ }^{19}$ reported the in vitro effect of Myricetin on high glucose-induced $\beta$-cell apoptosis, possibly via cyclin-dependent kinase 5 (CDK5) inhibition. Myricetin $(20 \mu \mathrm{M})$ significantly protect $\beta$-cells reducing apoptosis in INS-1 cells and rat islets that were incubated with glucose at the concentration of $30 \mathrm{mM}$ for 24 and $48 \mathrm{~h}$, respectively.

Many countries have developed and marketed health products containing Myricetin. Its antioxidant potentials and cholesterol-lowering effect have been acknowledged. Nowadays, people pay more attention in finding ways to strengthen the body using plant based natural products instead of using chemical drugs that have more toxic and side effects, this aspect encourage scientists to take-up research on Myricetin. As a result, studies focusing on its pharmacological effects are available, but a complete report on pharmacological activity of Myricetin is still lacking. Therefore, ADMET reports pertaining to Myricetin has been envisaged to provide a theoretical baseline support for the development of Myricetin based drugs for clinical use in the days to come.

Ramya et al. ${ }^{20}$ pointed out that, all parts of $S$. cumini are rich in polyphenols (Table 1). The extracts of various parts of $S$. cumini contains phytochemicals including tannins, anthocyanins, terpenes, flavanols and aliphatic-acids. Both fruit and flowers of $S$. cumini are rich in anthocyanins as Cyanidin, Delphinidin, Peonidin, Pelargonidin, Petunidin and Malvidin ${ }^{21}$. Seeds of $S$. cumini contain Rutin and Quercetin while leaves have been reported to contain kaempferol, Myricetin, Quercetin and their glycosides. S. cumini has been reported to contain Ellagic acid, Triterpenoids, acetyl Oleanolic acid, Quercetin, Isoquercitin, Myricetin and Kaempferol20. S. cumini possesses enormous phytochemicals, of all, Myricetin has been widely reported for hypoglycemic, antimicrobial, hypolipidemic, anti-allergic, antiinflammatory, cardio-protective, hepatoprotective and antineoplastic properties $3,6,20,22$.

Table 1: Myricetin in different parts of Syzygium cumini

\begin{tabular}{|c|c|c|}
\hline Part & Plant Based Natural Products (Bioactive Lead Molecules) & Ref \\
\hline Bark & Myricetin, Quercetin, Kaempferol & 20,47 \\
\hline Flower & $\begin{array}{l}\text { Kaempferol, Myricetin, Dihydromyricetin, Myricetin-3-L-Arabinoside, Isoquercetin, Quercetin, } \\
\text { Quercetin-3-D-galactoside }\end{array}$ & 20,48 \\
\hline Fruit & Myricetin, Quercetin, Myricetin Deoxyhexoside & 20,49 \\
\hline Leaf & $\begin{array}{l}\text { Catechin, Kaempferol, Myricetin, Myricetin 3-O-B-D-glucuronopyranoside, Myricetin-4 } \text {-methyl ether 3- } \\
\text { O-A-rhamnopyranoside, Myricetrin } 4 \quad \text {-0-acetate, Myricetrin } 4 \quad \text {-0-acetyl-2-o-gallate, Quercetin -3-o- } \\
\text { a-rhamno_pyranoside }\end{array}$ & 20,50 \\
\hline Seed & Quercetin, Myricetin, Rutin, 3,5,7,4-tetrahydroxy flavanone & 20,51 \\
\hline
\end{tabular}




\section{MATERIALS AND METHODS}

\section{ADMET prediction}

Physicochemical properties were computed using FAFDrugs4 (28961788)/ RDKit - open-source CIP. Selected phytocompounds were subjected to ADMET prediction using QikProp (version 4.3, Suite 2015-1; Schrödinger, LLC: New York, NY) and toxicity prediction using TOPKAT (Accelrys, Inc., USA). Qik-Prop develops and employs QSAR/QSPR models using partial least squares, principal component analysis and multiple linear regression to predict physicochemically significant descriptors ${ }^{23}$. Druggabiity scores were computed using FAF-Drugs4 (28961788)/ FAF-QED (28961788) - open-source CIP.

\section{RESULTS AND DISCUSSION}

In the present study, the selected biomolecule Myricetin -

Chemical kingdom: Organic compounds

Super class: Phenylpropanoids and polyketides

Class: Flavonoids

Subclass: Flavans

PubChem Identifier: 161557

ChEBI Identifier: 28429

Synonyms: DIHYDROMYRICETIN

Canonical SMILES:

Oc1cc2O[C@H](c3cc(0)c(c(c3)0)0)[C@H](C(=0)c2c(c1)0)O

\section{InChI Key: KJXSIXMJHKAJOD-LSDHHAIUSA-N}

Myricetin was evaluated for its Physico-chemical, ADMET and Drugable properties. The 2D and the 3D structures of the molecules have been provided in Fig. 1 and Fig. 2. The calculated molecular weight of the selected molecule was $320.25 \mathrm{~g} / \mathrm{mol}$; the $\log \mathrm{P}$ value of Myricetin was 0.89; $\log \mathrm{D}$ value of the compound was 1.36; calculated LogSw value of the compound was -2.38; total number of stereocenters were $=2$; Stereochemical complexity was estimated as 0.133; calculated Fsp3 value of Myricetin was $=0.133$; Topological polar surface area of Myricetin was = $147.68 \AA 2$; the number of hydrogen bond donors in the compound was $=6$; number of hydrogen bond acceptors in Myricetin was = 8; number of smallest set of smallest rings (SSSR) in Myricetin $=2$; size of the biggest system ring was 10; number of rotatable bond was $=1$; number of rigid bonds in Myricetin =18; number of charged groups in the compound $=0$; total charge of the compound was $=0$; the calculated Number of carbon atoms were 15; calculated Number of heteroatoms was $=8$; the calculated Number of heavy atoms in Myricetin was $=23$; the calculated ratio between the number of non-carbon atoms and the number of carbon atoms in Myricetin was $=0.53$. Summary of data for physicochemical properties is provided in Table 2.<smiles>O=C1c2c(O)cc(O)cc2O[C@@H](c2cc(O)c(O)c(O)c2)[C@@H]1O</smiles>

Figure 1: 2D structure of Myricetin

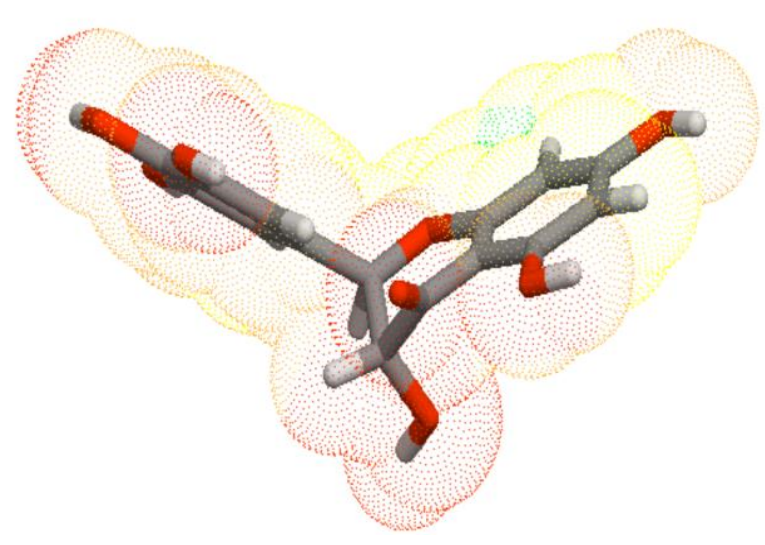

Figure 2: 3D structure of Myricetin

Table 2: Physicochemical Properties of Myricetin

\begin{tabular}{|c|c|}
\hline PHYSICOCHEMICAL PROPERTY & VALUE \\
\hline Molecular weight & $320.25 \mathrm{~g} / \mathrm{mol}$ \\
\hline $\log P$ & 0.89 \\
\hline $\log D$ & 1.36 \\
\hline LogSw & -2.38 \\
\hline Number of stereocenters & 2 \\
\hline Stereochemical complexity & 0.133 \\
\hline Fsp3 & 0.133 \\
\hline Topological polar surface area & $147.68 \AA 2$ \\
\hline Number of hydrogen bond donors & 6 \\
\hline Number of hydrogen bond acceptors & 8 \\
\hline $\begin{array}{l}\text { Number of smallest set of smallest rings } \\
\text { (SSSR) }\end{array}$ & 2 \\
\hline Size of the biggest system ring & 10 \\
\hline Number of rotatable bonds & 1 \\
\hline Number of rigid bonds & 18 \\
\hline Number of charged groups & 0 \\
\hline Total charge of the compound & 0 \\
\hline Number of carbon atoms & 15 \\
\hline Number of heteroatoms & 8 \\
\hline Number of heavy atoms & 23 \\
\hline $\begin{array}{l}\text { Ratio between the number of non- } \\
\text { carbon atoms and the number of carbon } \\
\text { atoms }\end{array}$ & 0.53 \\
\hline
\end{tabular}

The compound when tested for Human Intestinal Absorption (HIA+) recorded a calculated value with a probability of 0.965; Blood Brain Barrier (BBB-) had a probability value of 0.571, The compound when tested for overall ADMET properties Boiled egg model indicated that the compound lies will within the permissible limits (Fig. 3 ); Caco-2 permeable (Caco2-) had a probability value of 0.896 ; for Pglycoprotein substrate (Substrate) the calculated value had a probability $=0.563 ;$ P-glycoprotein inhibitor I (Non- 
inhibitor) recorded a calculated value with a probability of 0.930; while for P-glycoprotein inhibitor II (Non-inhibitor) the calculated value (probability) was $=0.838$. for CYP450 2C9 substrate (Non-substrate) the calculated value had probability of 0.790; CYP450 2D6 substrate (Non-substrate) the calculated value had probability of 0.912 ; CYP450 3A4 substrate (Non-substrate) the calculated value had probability of 0.653 ; CYP450 1A2 inhibitor (Inhibitor) the calculated value had a probability of 0.911 ; CYP450 2C9 inhibitor (Non-inhibitor) the calculated value had a probability of 0.582; CYP450 2D6 inhibitor (Non-inhibitor) the calculated value had a probability of 0.929 ; CYP450 2C19 inhibitor (Non-inhibitor) the calculated value had a probability of 0.903 ; CYP450 3A4 inhibitor (Inhibitor) the calculated value had a probability of 0.695 ; CYP450 inhibitory promiscuity (High CYP Inhibitory Promiscuity) the calculated value had a probability of 0.582 .

Ames test (Non AMES toxic) the calculated value had a probability of 0.722 ; Carcinogenicity (Non-carcinogens) the calculated value had a probability of 0.945 ; Biodegradation (Not ready biodegradable) the calculated value had a probability of 0.867 ; Rat acute toxicity $(3.020 \mathrm{LD} 50, \mathrm{~mol} / \mathrm{kg})$ the calculated value had a probability was Not applicable; hERG inhibition (predictor I) (Weak inhibitor) the calculated value had a probability of 0.978 ; hERG inhibition (predictor II) (Non-inhibitor) the calculated value had a probability of 0.816. Summary of ADMET properties tested has been provided in Table 3 .

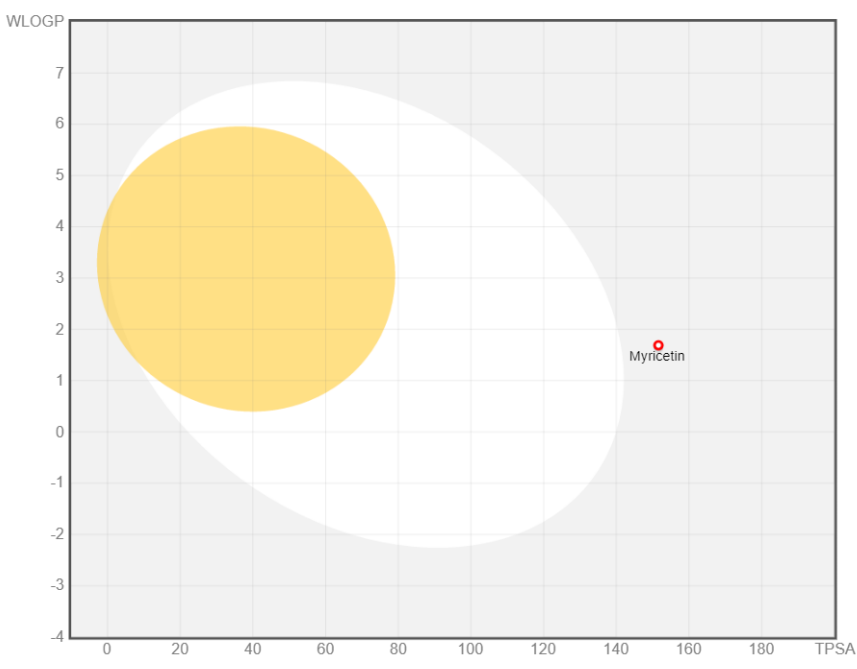

Figure 3: ADMET Boiled Egg Model of Myricetin

Table 3: ADMET Properties of Myricetin

\begin{tabular}{|c|c|c|}
\hline ADMET PROPERTY & VALUE & PROBABILITY \\
\hline Human Intestinal Absorption & HIA+ & 0.965 \\
\hline Blood Brain Barrier & BBB- & 0.571 \\
\hline Caco-2 permeable & Caco2- & 0.896 \\
\hline P-glycoprotein substrate & Substrate & 0.563 \\
\hline P-glycoprotein inhibitor I & Non-inhibitor & 0.930 \\
\hline P-glycoprotein inhibitor II & Non-inhibitor & 0.838 \\
\hline CYP450 2C9 substrate & Non-substrate & 0.790 \\
\hline CYP450 2D6 substrate & Non-substrate & 0.912 \\
\hline CYP450 3A4 substrate & Non-substrate & 0.653 \\
\hline CYP450 $1 A 2$ inhibitor & Inhibitor & 0.911 \\
\hline CYP450 2 C9 inhibitor & Non-inhibitor & 0.582 \\
\hline CYP450 2D6 inhibitor & Non-inhibitor & 0.929 \\
\hline CYP450 2C19 inhibitor & Non-inhibitor & 0.903 \\
\hline CYP450 3A4 inhibitor & Inhibitor & 0.695 \\
\hline CYP450 inhibitory promiscuity & High CYP Inhibitory Promiscuity & 0.582 \\
\hline Ames test & Non AMES toxic & 0.722 \\
\hline Carcinogenicity & Non-carcinogens & 0.945 \\
\hline Biodegradation & Not ready biodegradable & 0.867 \\
\hline Rat acute toxicity & $3.020 \mathrm{LD} 50, \mathrm{~mol} / \mathrm{kg}$ & Not applicable \\
\hline hERG inhibition (predictor I) & Weak inhibitor & 0.978 \\
\hline hERG inhibition (predictor II) & Non-inhibitor & 0.816 \\
\hline
\end{tabular}


Lipinski's rule of 5 violations for the compound was recorded as 1; the compound is within the range of Veber rule and was ascertained as Good; likewise it is in the limits of Egan rule and therefore considered as Good; Oral PhysChem score (Traffic Lights) was recorded as 2; GSK's 4/400 score was Good; Pfizer's 3/75 score was Good; Weighted quantitative estimate of drug-likeness (QEDw) score was 0.418; Solubility value for the compound was = 29492.46; Solubility Forecast Index was Good for Myricetin (Table 4). The calculated molecular and bioactivity score for the compound Myricetin is given in Table 6, 7.

Table 4: Druggability Properties of Myricetin

\begin{tabular}{|l|l|}
\hline DRUGGABILITY PROPERTY & VALUE \\
\hline Lipinski's rule of 5 violations & 1 \\
\hline Veber rule & Good \\
\hline Egan rule & Good \\
\hline $\begin{array}{l}\text { Oral PhysChem score (Traffic } \\
\text { Lights) }\end{array}$ & 2 \\
\hline GSK's 4/400 score & Good \\
\hline Pfizer's 3/75 score & Good \\
\hline $\begin{array}{l}\text { Weighted quantitative estimate } \\
\text { of drug-likeness (QEDw) score }\end{array}$ & 0.418 \\
\hline Solubility & 29492.46 \\
\hline Solubility Forecast Index & Good Solubility \\
\hline
\end{tabular}

Table 5: Molecular Properties - Calculated values of Myricetin

\begin{tabular}{|l|l|}
\hline MOLECULAR PROPERTY & VALUE \\
\hline miLogP & 0.42 \\
\hline TPSA & 147.67 \\
\hline Natoms & 23 \\
\hline MW & 320.25 \\
\hline nON & 8 \\
\hline nOHNH & $\mathbf{6}$ \\
\hline Nviolations & $\mathbf{1}$ \\
\hline Nrotb & 1 \\
\hline Volume & 254.34 \\
\hline
\end{tabular}

Table 6: Bioactivity scores - Calculated values of Myricetin

\begin{tabular}{|l|l|}
\hline BIOACTIVITY PROPERTY & VALUE \\
\hline GPCR ligand & 0.09 \\
\hline Ion channel modulator & 0.03 \\
\hline Kinase inhibitor & 0.01 \\
\hline Nuclear receptor ligand & $\mathbf{0 . 2 7}$ \\
\hline Protease inhibitor & $\mathbf{0 . 0 8}$ \\
\hline Enzyme inhibitor & $\mathbf{0 . 3 2}$ \\
\hline
\end{tabular}

Table 7: Predicted Human Target Proteins

\begin{tabular}{|l|l|l|}
\hline Protein identifier & $\begin{array}{l}\text { HGNC } \\
\text { symbol }\end{array}$ & $\begin{array}{l}\text { Combined score } \\
\text { STITCH database }\end{array}$ \\
\hline ENSP00000354558 & mTOR & 700 \\
\hline ENSP00000216117 & HMOX1 & 800 \\
\hline ENSP00000261769 & CDH1 & 800 \\
\hline ENSP00000386884 & CXCR4 & 800 \\
\hline ENSP00000313681 & SPHK1 & 700 \\
\hline
\end{tabular}

Myricetin when evaluated for its Human Target Proteins listed in the Human Genome Organisation (HUGO) Project for its effect on Predicted Human Target Protein with Protein Identifier Number (PIN) ENSP00000354558 (mTOR) protein kinase nucleates a major eukaryotic signalling network that coordinates cell growth with environmental conditions and plays a fundamental role in cell and organismal physiology, recorded a combined score of 700; PIN ENSP00000216117 (HMOX1), a Heme oxygenase cleaves the heme ring at the alpha methane bridge to form biliverdin. Biliverdin is subsequently converted to bilirubin by biliverdin reductase recorded a combined score of 800 ; PIN ENSP00000261769 (CDH1), Cdh1 is one of the substrate adaptor protein of the anaphase-promoting complex (APC); plays a pivotal role in controlling cell division at the end of mitosis (telophase) and in the subsequent G1 phase of cell cycle recorded a combined score of 800 ;

Likewise, PIN ENSP00000386884 (CXCR4) C-X-C chemokine receptor type 4 also known as fusin or CD184 is a protein that in humans is encoded by the CXCR4 gene recorded a combined score of 800; PIN ENSP00000313681 (SPHK1) Sphingosine kinase 1 phosphorylates sphingosine to sphingosine-1-phosphate (S1P) SK1 is normally a cytosolic protein but is recruited to membranes rich in phosphatidate (PA), a product of Phospholipase D (PLD) recorded a combined score of 700 in the STITCH database respectively. Overall results indicated that this lead molecule is of GRAS standard and can be used on the Human Target Protein candidates tested (Table 7). The cytoscape network of predicted human target of Myricetin is provided in Fig. 4. The Predicated $\mathrm{Pa}-\mathrm{Pi}-\mathrm{Pmax}$ and the probable bioactivity of the compound are given in Table 8.

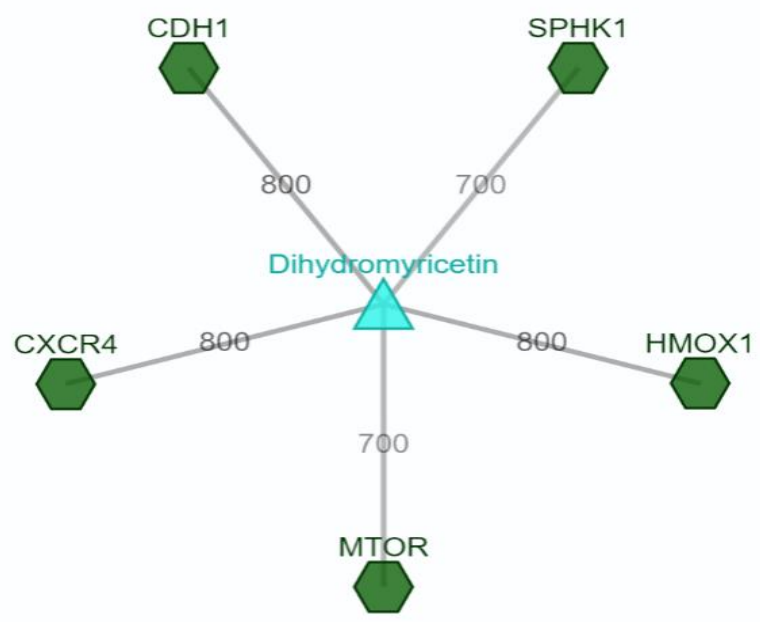

Figure 4: Cytoscape network of predicted human targets of Myricetin 
Table 8 Predicated Pa-Pi-Pmax and bioactivity of Myricetin

\begin{tabular}{|c|c|c|c|}
\hline $\mathbf{P a}$ & $\mathbf{P i}$ & Pmax & Bio-Activity \\
\hline 0.964 & 0.001 & 0.964 & Peroxidase inhibitor \\
\hline 0.948 & 0.001 & 0.948 & Cystathionine beta-synthase inhibitor \\
\hline 0.903 & 0.004 & 0.903 & Apoptosis agonist \\
\hline 0.869 & 0.003 & 0.897 & Antioxidant \\
\hline 0.867 & 0.002 & 0.981 & Monophenol monooxygenase inhibitor \\
\hline 0.86 & 0.004 & 0.860 & Aldehyde oxidase inhibitor \\
\hline 0.839 & 0.001 & 0.839 & Carbonic anhydrase III inhibitor \\
\hline 0.818 & 0.001 & 0.818 & Fatty acid synthase inhibitor \\
\hline 0.811 & 0.001 & 0.811 & Creatine kinase inhibitor \\
\hline 0.807 & 0.003 & 0.807 & Interleukin 4 antagonist \\
\hline 0.789 & 0.002 & 0.789 & Carbonic anhydrase VI inhibitor \\
\hline 0.784 & 0.004 & 0.784 & Lipoxygenase inhibitor \\
\hline 0.782 & 0.002 & 0.945 & Carbonic anhydrase XIII inhibitor \\
\hline 0.764 & 0.002 & 0.764 & Xanthine dehydrogenase inhibitor \\
\hline 0.754 & 0.007 & 0.754 & Transcription factor NF kappa B inhibitor \\
\hline 0.712 & 0.003 & 0.712 & NOS3 expression enhancer \\
\hline 0.692 & 0.004 & 0.692 & Pyruvate kinase inhibitor \\
\hline 0.687 & 0.002 & 0.708 & Xanthine oxidase inhibitor \\
\hline 0.672 & 0.002 & 0.672 & Histone deacetylase SIRT1 stimulant \\
\hline 0.672 & 0.002 & 0.672 & Histone deacetylase stimulant \\
\hline 0.655 & 0.014 & 0.759 & Antiinflammatory \\
\hline 0.632 & 0.002 & 0.632 & DOPA decarboxylase inhibitor \\
\hline 0.631 & 0.004 & 0.631 & Estrogen antagonist \\
\hline 0.618 & 0.003 & 0.618 & Estrogen receptor beta antagonist \\
\hline 0.609 & 0.003 & 0.609 & HIV-1 integrase (3'-Processing) inhibitor \\
\hline 0.604 & 0.006 & 0.938 & Hepatoprotectant \\
\hline 0.602 & 0.006 & 0.692 & Hypoxia inducible factor 1 alpha inhibitor \\
\hline 0.600 & 0.002 & 0.613 & Carbonic anhydrase VII inhibitor \\
\hline 0.584 & 0.004 & 0.584 & P-glycoprotein inhibitor \\
\hline 0.578 & 0.009 & 0.905 & Hypoglycemic \\
\hline 0.562 & 0.017 & 0.873 & Spasmolytic \\
\hline 0.561 & 0.004 & 0.851 & Lipid peroxidase inhibitor \\
\hline 0.533 & 0.013 & 0.533 & Transcription factor STAT inhibitor \\
\hline 0.514 & 0.002 & 0.514 & NAD(P)H dehydrogenase (quinone) inhibitor \\
\hline 0.512 & 0.004 & 0.512 & Topoisomerase II inhibitor \\
\hline 0.511 & 0.003 & 0.511 & HIV-1 integrase (Strand Transfer) inhibitor \\
\hline 0.506 & 0.008 & 0.771 & Angiogenesis stimulant \\
\hline 0.503 & 0.011 & 0.503 & Heat shock protein 90 antagonist \\
\hline 0.500 & 0.003 & 0.500 & HIV-1 integrase inhibitor \\
\hline 0.493 & 0.003 & 0.493 & Telomerase inhibitor \\
\hline
\end{tabular}


Studies on Myricetin has been surmounting in recent times due to its overwhelmed biological role in human healthcare $^{6,24}$. Myricetin plays an important role as antioxidant ${ }^{16}$, anticancer ${ }^{25,26}$, anti-inflammatory ${ }^{27,28}$, anti-amyloidogenic ${ }^{29}$, antibacterial ${ }^{30}$, antiviral ${ }^{31}$, and antidiabetic ${ }^{32}$ agent. Myricetin has a proven record of an inverse association with risk of $\mathrm{T}_{2} \mathrm{D}^{33}$. In Myricetin, aryloxy radical in B-ring promotes antioxidant activity due to the presence of a pyrogallol moiety with a $3^{\prime}, 4^{\prime}, 5^{\prime}$-trihydroxy-substituted phenyl group (FRS) than a catechol moiety ${ }^{34}$. Therefore, Myricetin has been proposed to be a potent antioxidant ${ }^{35}$.

Diabetes has a close association with metabolic inflammation and oxidative stress. Chronic inflammatory responses, including production of cytokines, results impaired insulin secretion and $\beta$-cell dysfunction that ultimately leads to diabetes ${ }^{36}$. Therefore, production and elimination of ROS is an important step in the pathogenesis of diabetes ${ }^{37}$. Myricetin has antioxidant as well as antiinflammatory effects therefore, plays a pivotal role in preventing the onset of diabetics and the long term complications associated with the disease ${ }^{38}$. It has been demonstrated that Myricetin significantly lowers the plasma glucose levels in streptozotocin-induced diabetes in rats ${ }^{39}$ and insulin resistance ${ }^{40}$. Myricetin inhibits glucose uptake in rat adipocytes by disrupting glucose-transporter subtype 4 (GLUT4). Furthermore, Myricetin blocks metabolic uptake of methylglucose by inhibiting GLUT4. However, phosphorylation of insulin receptor substrate-1 via insulin receptor tyrosine kinase remains unaffected by Myricetin in insulin-stimulated rat adipocytes ${ }^{41}$.

ATPases use ATP for catalytic function; several ATPases such as Hsp70 ATPase ${ }^{42}$ are inhibited by Myricetin. Toxicological screenings including behavioral, histomorphological, hematological and biochemical parameters using seed extracts 43 , fruit ${ }^{44}$, and leaf ${ }^{45}$ of $S$. cumini, had no toxic effect. Silva et al. ${ }^{45}$ demonstrated that acute administration of hydro-alcoholic extract of $S$. cumini leaf at doses as high as 2 $\mathrm{g} / \mathrm{kg}$ produced no toxic effects in experimental models. Dang et al.46 demonstrated that owing to poor absorption, Myricetin showed low oral bioavailability. Studies have established that Myricetin has a therapeutic effect on different types of tumors, inflammatory diseases, atherosclerosis, thrombosis, cerebral ischemia, diabetes, Alzheimer's disease and pathogenic microbial infections ${ }^{6}$. Furthermore, Myricetin significantly enhances the immunomodulatory functions, suppresses cytokine storms, and improves cardiac-dysfunction. Myricetin possesses an antiviral potential, therefore, can be used as an adjuvant treatment against COVID-19 and other viral infections due to its physiochemical and biomolecular properties.

\section{CONCLUSION}

Prevention and cure of diseases using phytochemicals especially flavonoids has been well established. Fruits and vegetables are rich sources of flavonoids. Myricetin has a potential use as a nutraceutical. Its antimicrobial and antioxidant role have shown promising results. Also, preclinical studies have revealed antidiabetic, anticancer, immunomodulatory, anti-cardiovascular, analgesic and antihypertensive activities. The data presented in this paper towards physicochemical, ADMET and druggable properties of Myricetin can used as a baseline information to take-up in-depth research investigation on this molecule as a lead GRAS candidate for the development of novel drug in the days to come.

\section{REFERENCES}

1. Kong M, Xie K, Lv M, Li J, Yao J, Yan K, Wu X, Xu Y, Ye D. Antiinflammatory phytochemicals for the treatment of diabetes and its complications: Lessons learned and future promise. Biomedicine \& Pharmacotherapy. 2021; 133:110975. https://doi.org/10.1016/j.biopha.2020.110975

2. Newman DJ, Cragg GM. Natural products as sources of new drugs over the last 25 years. Journal of natural products. 2007; 70(3):461-77. https://doi.org/10.1021/np068054v

3. Ahmed R, Tariq M, Hussain M, Andleeb A, Masoud MS, Ali I, Mraiche F, Hasan A. Phenolic contents-based assessment of therapeutic potential of Syzygium cumini leaves extract. PloS one $2019 ; 14(8): \mathrm{e} 0221318$. https://doi.org/10.1371/journal.pone.0221318

4. Kumar S, Pandey AK (2013) Chemistry and biological activities of flavonoids: an overview. Scientific World Journal 2013; 162750 https://doi.org/10.1155/2013/162750

5. Middleton EJ Effect of plant flavonoids on immune and inflammatory cell function Advances in Experimental Medicine and Biology 1998; 439:175-182 https://doi.org/10.1007/9781-4615-5335-9_13

6. Song X, Tan L, Wang M, Ren C, Guo C, Yang B, Ren Y, Cao Z, Li Y, Pei J (2021) Myricetin: A review of the most recent research. Biomedicine and Pharmacotherapy 134:111017. https://doi.org/10.1016/j.biopha.2020.111017

7. Perkin AG, Hummel JJ. LXXVI.-The coloring principle contained in the bark of Myrica nagi. Part I. Journal of the Chemical Society, Transactions. 1896; 69:1287-94 https://doi.org/10.1039/CT8966901287

8. Ong KC, Khoo HE Biological effects of Myricetin. General Pharmacology: The Vascular System 1997; 29(2):121-126. https://doi.org/10.1016/S0306-3623(96)00421-1

9. Jones JR, Lebar MD, Jinwal UK, Abisambra JF, Koren III J, Blair L, O'Leary JC, Davey Z, Trotter J, Johnson AG, Weeber E The diarylheptanoid (+)-a R, 11 S-myricanol and two flavones from bayberry (Myrica cerifera) destabilize the microtubuleassociated protein Tau. Journal of natural products 2011; 74(1):38-44 https://doi.org/10.1021/np100572z

10. Ayyappan P, Ganesan K, Jayakumararaj R Ethnobotanic information on uncommon anti-diabetic medicinal plants from Alagarkoil forest reserve: Evidence based strategic rationale in management of diabetics. Int J Pharm Res 2019; 16:515-26

11. Umadevi I, Daniel M, Sabnis SD Chemotaxonomic studies on some members of Anacardiaceae Proceedings: Plant Sciences 1988; 98(3):205-208

12. Abd El-kader AM, El-Readi MZ, Ahmed AS, Nafady AM, Wink M, Ibraheim ZZ Polyphenols from aerial parts of Polygonum bellardii and their biological activities. Pharmaceutical Biology 2013; 51(8):1026-34 https://doi.org/10.3109/13880209.2013.775160

13. Chua LS, Latiff NA, Lee SY, Lee CT, Sarmidi MR, Aziz RA Flavonoids and phenolic acids from Labisia pumila (Kacip Fatimah). Food Chemistry 2011; 127(3):1186-1192. https://doi.org/10.1016/j.foodchem.2011.01.122

14. Lee KM, Kang NJ, Han JH, Lee KW, Lee HJ Myricetin downregulates phorbol ester-induced cyclooxygenase-2 expression in mouse epidermal cells by blocking activation of nuclear factor kappa B. Journal of Agricultural and Food Chemistry 2007; 55(23):9678-84. https://doi.org/10.1021/jf0717945

15. Semwal DK, Semwal RB, Combrinck S, Viljoen A Myricetin: A dietary molecule with diverse biological activities. Nutrients 2016; 8(2):90-97 https://doi.org/10.3390/nu8020090

16. Ong KC, Khoo HE Insulinomimetic effects of myricetin on lipogenesis and glucose transport in rat adipocytes but not glucose transporter translocation. Biochemical Pharmacology 1996; 51(4):423-9. https://doi.org/10.1016/00062952(95)02195-7

17. Li Y, Zheng X, Yi X, Liu C, Kong D, Zhang J, Gong M Myricetin: a potent approach for the treatment of type 2 diabetes as a natural class B GPCR agonist. FASEB J 2017; 31(6):2603-2611. https://doi.org/10.1096/fj.201601339R

18. Kwon O, Eck P, Chen S, Corpe CP, Lee JH, Kruhlak M, Levine M Inhibition of the intestinal glucose transporter GLUT2 by flavonoids. The FASEB Journal 2007; 21(2):366-377. https://doi.org/10.1096/fj.06-6620com 
19. Karunakaran U, Elumalai S, Moon JS, Jeon J-H, Kim ND, Park K-G, Won KC, Leem J, Lee I-K Myricetin protects against high glucoseinduced $\beta$-cell apoptosis by attenuating endoplasmic reticulum stress via inactivation of cyclin-dependent kinase 5 . Diabetes Metab J 2019; 43(2):192-205 https://doi.org/10.4093/dmj.2018.0052

20. Ramya S, Neethirajan K, Jayakumararaj R. Profile of bioactive compounds in Syzygium cumini-a review. J. Pharm. Res 2012; 5(8):4548-4553.

21. Aqil F, Gupta A, Munagala R, Jeyabalan J, Kausar H, Sharma RJ Antioxidant and antiproliferative activities of anthocyanin/ellagitannin-enriched extracts from Syzygium cumini L.(Jamun, the Indian Blackberry). Nutrition and Cancer 2012; 64(3):428-38. https://doi.org/10.1080/01635581.2012.657766

22. Gaspar RS, da Silva SA, Stapleton J, Fontelles JL, Sousa HR, Chagas VT, Alsufyani S, Trostchansky A, Gibbins JM, Paes AM. Myricetin, the main flavonoid in Syzygium cumini leaf, is a novel inhibitor of platelet thiol isomerases PDI and ERp5. Frontiers in Pharmacology. 2020; 10:1678. https://doi.org/10.3389/fphar.2019.01678

23. Zhou Y, Wu F, Li L, Shen X, Chen G, Wang X, Liang X, Tan M, Huang Z. Computational approaches in preclinical studies on drug discovery and development. Frontiers in Chemistry. 2020; 8:726-31. https://doi.org/10.3389/fchem.2020.00726

24. Park KS, Chong Y, Kim MK Myricetin: biological activity related to human health. Applied Biological Chemistry 2016; 59(2):25969 https://doi.org/10.1007/s13765-016-0150-2

25. Holder S, Zemskova M, Zhang C, Tabrizizad M, Bremer R, Neidigh JW, Lilly MB, Characterization of a potent and selective smallmolecule inhibitor of the PIM1 kinase. Mol Cancer Ther 2007; 6:163-172 https://doi.org/10.1158/1535-7163.MCT-06-0397

26. Phillips PA, Sangwan V, Borja-Cacho D, Dudeja V, Vickers SM, Saluja AK. Myricetin induces pancreatic cancer cell death via the induction of apoptosis and inhibition of the phosphatidylinositol 3-kinase (PI3K) signaling pathway. Cancer Letters. 2011; 308(2):181-8. https://doi.org/10.1016/j.canlet.2011.05.002

27. Tsai SH, Liang YC, Lin-Shiau SY, Lin JK. Suppression of TNF $\alpha$-mediated NFkb activity by myricetin and other flavonoids through downregulating the activity of IKK in ECV304 cells. Journal of Cellular Biochemistry. 1999; 74(4):606-15. https://doi.org/10.1002/(SICI)10974644(19990915)74:4<606::AID-JCB10>3.0.CO;2-W

28. Wang SJ, Tong Y, Lu S, Yang R, Liao X, Xu YF, Li X. Antiinflammatory activity of myricetin isolated from Myrica rubra Sieb. et Zucc. leaves. Planta Medica. 2010; 76(14):1492-6. https://doi.org/10.1055/s-0030-1249780

29. Sato M, Murakami K, Uno M, Nakagawa Y, Katayama S, Akagi KI, Masuda Y, Takegoshi K, Irie K. Site-specific inhibitory mechanism for amyloid $\beta 42$ aggregation by catechol-type flavonoids targeting the Lys residues. Journal of Biological Chemistry. 2013; 288(32):23212-24. https://doi.org/10.1074/jbc.M113.464222

30. Xu H, Ziegelin G, Schröder W, Frank J, Ayora S, Alonso JC, Lanka E, Saenger W. Flavones inhibit the hexameric replicative helicase RepA. Nucleic Acids Research. 2001; 29(24):5058-66. https://doi.org/10.1093/nar/29.24.5058

31. Pasetto S, Pardi V, Murata RM. Anti-HIV-1 activity of flavonoid myricetin on HIV-1 infection in a dual-chamber in vitro model. PLoS One. 2014; 9(12):e115323. https://doi.org/10.1371/journal.pone.0115323

32. Li Y, Ding Y. Minireview: Therapeutic potential of myricetin in diabetes mellitus. Food Science and Human Wellness. 2012; 1(1):19-25. https://doi.org/10.1016/j.fshw.2012.08.002

33. Zamora-Ros R, Forouhi NG, Sharp SJ, Gonzalez CA, Buijsse B, Guevara M, van der Schouw YT, Amiano P, Boeing H, Bredsdorff L, Fagherazzi G. Dietary intakes of individual flavanols and flavonols are inversely associated with incident type 2 diabetes in European populations. The Journal of Nutrition. 2014; 144(3):335-43. https://doi.org/10.3945/jn.113.184945

34. Furuno K, Akasako T, Sugihara N. The contribution of the pyrogallol moiety to the superoxide radical scavenging activity of flavonoids. Biological and Pharmaceutical Bulletin. 2002; 25(1):19-23. https://doi.org/10.1248/bpb.25.19
35. Gordon MH, Roedig-Penman A. Antioxidant activity of quercetin and myricetin in liposomes. Chemistry and Physics of Lipids. 1998; 97(1):79-85. https://doi.org/10.1016/S00093084(98)00098-X

36. Hotamisligil GS. Inflammation and metabolic disorders. Nature. 2006; 444(7121):860-7. https://doi.org/10.1038/nature05485

37. Cheng X, Siow RC, Mann GE. Impaired redox signaling and antioxidant gene expression in endothelial cells in diabetes: a role for mitochondria and the nuclear factor-E2-related factor 2 Kelch-like ECH-associated protein 1 defense pathway. Antioxidants \& Redox Signaling. 2011; 14(3):469-87. https://doi.org/10.1089/ars.2010.3283

38. Pandey KB, Mishra N, Rizvi SI. Myricetin may provide protection against oxidative stress in type 2 diabetic erythrocytes. Zeitschrift für Naturforschung C. 2009; 64(9-10):626-30. https://doi.org/10.1515/znc-2009-9-1004

39. Liu IM, Liou SS, Lan TW, Hsu FL, Cheng JT. Myricetin as the active principle of Abelmoschus moschatus to lower plasma glucose in streptozotocin-induced diabetic rats. Planta Medica. 2005l; 71(07):617-21. https://doi.org/10.1055/s-2005-871266

40. Tzeng TF, Liou SS, Liu IM. Myricetin ameliorates defective postreceptor insulin signaling via $\beta$-endorphin signaling in the skeletal muscles of fructose-fed rats. Evidence-Based Complementary and Alternative Medicine. 2011; 150752 https://doi.org/10.1093/ecam/neq017

41. Strobel P, Allard C, Perez-Acle T, Calderon R, Aldunate R, Leighton F. Myricetin, quercetin and catechin-gallate inhibit glucose uptake in isolated rat adipocytes. Biochemical Journal. 2005; 386(3):471-8. https://doi.org/10.1042/BJ20040703

42. Koren J, Jinwal UK, Jin Y, O'Leary J, Jones JR, Johnson AG, Blair LJ, Abisambra JF, Chang L, Miyata Y, Cheng AM. Facilitating Akt clearance via manipulation of Hsp70 activity and levels. Journal of Biological Chemistry. 2010; 285(4):2498-505. https://doi.org/10.1074/jbc.M109.057208

43. Chaturvedi A, Kumar MM, Bhawani G, Chaturvedi H, Kumar M, Goel RK. Effect of ethanolic extract of Eugenia jambolana seeds on gastric ulceration and secretion in rats. Indian Journal of Physiology and Pharmacology. 2007; 51(2):131.

44. Kumar A, Ilavarasan R, Deecaraman M, Aravindan P, Padmanabhan N, Krishan MR. Anti-diabetic activity of Syzygium cumini and its isolated compound against streptozotocininduced diabetic rats. Journal of Medicinal Plants Research. 2013; 2(9):246-9.

45. Silva SD, Abreu IC, Silva GF, Ribeiro RM, Lopes AD, Cartágenes MD, Freire SM, Borges AC, Borges MO. The toxicity evaluation of Syzygium cumini leaves in rodents. Revista Brasileira de Farmacognosia. 2012; 22(1):102-8. https://doi.org/10.1590/S0102-695X2011005000181

46. Dang Y, Lin G, Xie Y, Duan J, Ma P, Li G, Ji G. Quantitative determination of myricetin in rat plasma by ultra-performance liquid chromatography tandem mass spectrometry and its absolute bioavailability. Drug Research. 2014; 64(10):516-22. https://doi.org/10.1055/s-0033-1363220

47. Chagas VT, França LM, Malik S, Paes AM. Syzygium cumini (L.) skeels: a prominent source of bioactive molecules against cardiometabolic diseases. Frontiers in Pharmacology. 2015; 6:259. https://doi.org/10.3389/fphar.2015.00259

48. Subramanian SS, Nair AG. Myricetin and myricetin-3-Olrhamnoside from the leaves of Madhuca indica and Achras sapota. Phytochemistry. 1972; 7:247-256

49. Gordon A, Jungfer E, da Silva BA, Maia JG, Marx F. Phenolic constituents and antioxidant capacity of four underutilized fruits from the Amazon region. Journal of agricultural and Food Chemistry. 2011; 59(14):7688-99. https://doi.org/10.1021/jf201039r

50. Mahmoud II, Marzouk MS, Moharram FA, El-Gindi MR, Hassan AM. Acylated flavonol glycosides from Eugenia jambolana leaves. Phytochemistry. 2001; 58(8):1239-44. https://doi.org/10.1016/S0031-9422(01)00365-X

51. Bhatia IS, Bajaj KL. Chemical constituents of the seeds and bark of Syzygium cumini. Planta Medica. 1975; 28(08):346-52. https://doi.org/10.1055/s-0028-1097868 